\title{
STRATEGI PENINGKATAN PENGETAHUAN IBU TENTANG PENALARAN INDUKSI DALAM PENDI- SIPLINAN ANAK PRA SEKOLAH MELALUI SEMINAR ONLINE
}

\author{
Ratih Puspa Rahmani, Lydia Freyani Hawadi \\ Fakultas Psikologi, Universitas Indonesia \\ Jl. Margonda Raya, Pondok Cina, Kecamatan Beji, Kota Depok, Jawa Barat 16424 \\ Email: pusparahmani@gmail.com
}

\begin{abstract}
ABSTRAK. Pada usia prasekolah, berbagai kemampuan anak meningkat, sehingga ekspektasi dan tuntutan sosial pada anak prasekolah pun semakin besar. Namun, masih ada beberapa keterbatasan yang dapat memicu munculnya perilaku negatif pada anak. Kondisi ini memicu orangtua menerapkan praktik pendisiplinan lebih ketat. Dalam menerapkan pendisiplinan, perlu dipilih strategi yang tepat dan efektif karena strategi pendisiplinan yang diterapkan pada anak sejak usia prasekolah dapat menentukan perkembangan anak di usia selanjutnya. Ibu merupakan sosok yang memegang peran penting dalam pendisiplinan anak. Penelitian ini bertujuan untuk melihat efektivitas seminar online dengan aplikasi Whatsapp Messenger dalam meningkatkan pengetahuan ibu tentang strategi penalaran induksi dalam pendisiplinan anak prasekolah. Penalaran induksi adalah teknik pendisiplinan yang menggunakan nalar dengan cara menyampaikan bagaimana perilaku anak dapat berdampak pada orang lain. Penelitian ini adalah penelitian terapan dengan one group pre-test post-test desigin. Populasi dalam penelitian ini adalah ibu yang memiliki anak berusia 3-5 tahun di daerah Jakarta Selatan dan Depok (Jawa Barat). Pemilihan subjek menggunakan teknik purposive sampling. Jumlah subjek dalam penelitian ini adalah sebanyak 14 orang. Data yang diperoleh berupa data kuantitatif dan tambahan data kualitatif. Data kuantitatif diperoleh melalui perbandingan skor pengetahuan subjek saat pre-test dan post-test. Sementara itu, data kualitatif diperoleh melalui wawancara dengan subjek. Temuan dari penelitian ini menunjukkan bahwa terdapat peningkatan yang signifkan pada pengetahuan subjek setelah mendapatkan intervensi. Oleh karena itu, dapat disimpulkan bahwa intervensi yang diberikan dalam bentuk seminar online efektif untuk meningkatkan pengetahuan ibu tentang strategi penalaran induksi dalam pendisiplinan anak prasekolah.
\end{abstract}

Kata kunci; disiplin; penalaran induksi; anak prasekolah; ibu; seminar online; Whatsapp Messenger

\section{STRATEGY FOR IMPROVING MOTHER'S KNOWLEDGE ABOUT INDUCTION REASONING IN DISCI- PLINING PRESCHOOLERS THROUGH ONLINE SEMINARS}

\begin{abstract}
At preschool age, important development in all areas increase, so that expectations and social demands on preschoolers are even greater. However, there are still some limitations on preschoolers that can trigger undesirable behavior. This condition triggers parents to apply strict or harsh disciplinary practices. In implementing discipline, appropriate and effective strategies need to be chosen because the disciplinary strategies applied to children from preschool age can affect children's later development. Mother is a figure who plays an important role in disciplining children. This study aims to look at the effectiveness of online seminars with the Whatsapp Messenger application in increasing maternal knowledge about induction reasoning strategies in disciplining preschool children. Induction reasoning is a discipline technique that uses reasoning by conveying how a child's behavior can affect others. This study is applied research with one group pre-test post-test design. The population in this study are mothers who have children aged 3-5 years in the areas of South Jakarta and Depok (West Java). This research uses a purposive sampling technique. The number of subjects in this study were 14 people. The data of this research are quantitative and qualitative data. Quantitative data were obtained through comparison of maternal knowledge scores about discipline strategy during pre-test and post-test. Meanwhile, qualitative data was obtained through interviews with participants after intervention. The findings from this study indicate that there is a significant increase in subject knowledge after getting the intervention. Therefore, it can be concluded that the interventions provided in the form of online seminars are effective for increasing mothers' knowledge about induction reasoning strategies in the discipline of preschool children.
\end{abstract}

Keyword; discipline; induction; preschool children; mother; online seminar; Whatsapp Messenger

\section{PENDAHULUAN}

Ibu merupakan sosok yang memegang peran penting dalam pengasuhan anak, termasuk dalam pendisiplinan. Penelitian oleh Hallers-Haalboom, Groeneveld, van Berkel, Endendijk, van der Pol, Bakermans-Kranenburg, dan Mesman. (2015) menunjukkan bahwa ibu lebih banyak menghabiskan waktu dalam pengasuhan anak diband- ingkan dengan ayah. Waktu pengasuhan yang lebih banyak diperankan oleh ibu berpengaruh pada tanggung jawab pendisiplinan yang lebih besar pada ibu, dibandingkan dengan ayah yang lebih banyak memiliki momen bersenang-senang saat bersama anak.

Selain itu, pentingnya peran ibu dalam pendisiplinan anak juga dapat dilihat dari dampak pendisiplinan ibu terhadap perkembangan anak. Penelitian yang dilakukan oleh 
Chang, Schwartz, Dodge, dan McBride-Chang (2003) meneliti tentang hubungan penerapan pengasuhan yang keras terhadap kemampuan regulasi emosi anak. Hasil penelitian tersebut menunjukkan bahwa kemampuan regulasi emosi anak lebih dipengaruhi oleh penerapan pengasuhan yang keras dari ibu dibandingkan ayah. Terdapat penelitian lain yang menunjukkan bahwa pengasuhan ibu yang kurang sensitif terhadap anak juga dapat berdampak pada kemampuan kognitif yang mengatur perilaku anak. Pengasuhan yang kurang sensitif dari ibu dapat menyebabkan kemampuan kognitif anak lebih rendah, khususnya dalam kemampuan emergent metacognition dan inhibitory self-control. Emergent metacognition berhubungan dengan kemampuan anak untuk melakukan inisiatif, membuat perencanaan, mengatur dan mengimplementasikan suatu hal, serta menyelesaikan masalah dengan memikirkan dampak jangka panjang. Sementara itu, inhibitory self-control meliputi kemampuan anak untuk mengatur tindakan, respon, emosi, dan perilaku yang sesuai dengan batasan (Lucassen, Kok, Bakermans-Kranenburg, Van Ijzendoorn, Jaddoe, Hofman, Verhulst, Lambregstse-Van den Berg \& Tiemeier, 2015). Dari penelitian Lucassen, et al. (2015) tersebut dapat dikatakan bahwa peran ibu dalam pengasuhan dapat berpengaruh terhadap kemampuan kognitif anak dalam mengatur perilakunya.

Selain itu, penelitian yang dilakukan oleh Ball, Smetana, Sturge-Apple, Suor, dan Skibo (2017) menunjukkan pendisiplinan yang dilakukan oleh ibu pada anak prasekolah berhubungan dengan kemampuan moral judgment anak, khususnya kemampuan anak dalam menilai baik atau buruknya suatu tindakan kekerasan. Hasil penelitian Ball, et al. tersebut menunjukkan bahwa ibu yang menerapkan pendisiplinan dengan keras dan tidak konsisten dapat menyebabkan rendahnya kemampuan moral judgment pada anak prasekolah. Berdasarkan hasil dari penelitian Chang, et al. (2003), Lucassen, et al. (2015), dan Ball, et al. (2017), menunjukkan bahwa peran ibu dalam pengasuhan dan pendisiplinan dapat berdampak pada perkembangan anak, baik dari kemampuan emosi, kognitif, maupun moralnya.

Salah satu faktor yang dapat menentukan pendisiplinan yang diterapkan dalam pola asuh anak adalah pengetahuan ibu. Penelitian yang dilakukan oleh Davidov, Grusec, dan Wolfe (2012) menunjukkan bahwa pengetahuan ibu tentang persepsi anak dalam hal pendisiplinan berkaitan dengan pola asuh yang diterapkan oleh ibu. Ibu yang memiliki pengetahuan lebih rendah cenderung menerapkan pola asuh otoriter atau permisif. Pola asuh yang diterapkan ini bepengaruh terhadap pandangan ibu tentang dampak pendisiplinan pada anak. Kaitan antara pengetahuan ibu dengan pendisiplinan anak juga diteliti oleh Saunders, McFarland-Piazza, Jacobvitz, Hazen-Swann, dan Burton (2013). Penelitian tersebut menunjukkan bahwa pemahaman ibu yang lebih baik secara kognitif berpengaruh terhadap kemampuan ibu menggunakan kalimat yang lebih positif dalam mengarahkan perilaku anak. Hal ini menunjukkan bahwa ibu perlu memahami tentang strategi pengasuhan dan pendisiplinan yang tepat.

Berkaitan dengan penerapan strategi pendisiplinan, usia prasekolah adalah periode yang tepat untuk menanamkan pendisiplinan pada anak. Hal ini dapat dilihat dari kemampuan yang sedang berkembang pada usia prasekolah. Secara fisik, pada usia prasekolah, bagian otak yang mengatur perencanaan dan pengaturan tindakan sedang berkembang dengan pesat. Secara kognitif, anak usia prasekolah juga sudah mulai memahami hubungan sebab-akibat dan mulai lebih banyak bertanya dengan kata tanya "mengapa?". Jika dilihat dari aspek sosioemosional, pada saat memasuki usia prasekolah, anak juga mulai memahami rasa bersalah jika perilakunya tidak sesuai dengan ekspektasi atau tuntutan orang di sekitarnya. Pada tahap ini, anak mulai memasuki kehidupan sosial yang lebih luas, sehingga anak akan belajar untuk menghadapi tantangan yang membutuhkan keaktifan, kejelasan tujuan, dan rasa tanggung jawab. Selain itu, pemahaman anak tentang perilaku prososial juga mulai muncul, walaupun anak belum berpikir bahwa tindakan prososial perlu dilakukan secara tulus karena keinginan dari dirinya sendiri (Santrock, 2011).

Di sisi lain, Sanders (1992) menjelaskan bahwa anak usia prasekolah masih banyak menunjukkan masalah-masalah perilaku. Masalah yang dapat muncul pada anak usia 3-5 tahun antara lain anak tidak mau mengikuti peraturan yang sudah ditentukan atau instruksi yang dikatakan oleh orangtua, anak susah ditenangkan saat tantrum, anak mengulur waktu di pagi hari, anak menolak makan atau memilih-milih makanan, anak mencari perhatian saat ada tamu, anak merengek di tempat umum, anak merasa bosan selama perjalanan, anak tidak mau menunggu kegiatan orangtua selesai, dan anak terlibat konflik dengan teman sebaya. Hal ini juga ditunjukkan dalam hasil studi pendahuluan yang dilakukan oleh peneliti terhadap 15 ibu di Jakarta yang memiliki anak usia 3-5 tahun. Hasil studi pendahuluan tersebut menunjukkan bahwa ibu yang memiliki anak berusia 3-5 tahun masih mengeluhkan beberapa perilaku anaknya. Sebanyak $40 \%$ ibu mengeluhkan perilaku anak saat marah jika keinginannya tidak terpenuhi, 33\% ibu mengeluhkan perilaku anak saat susah diatur, 27\% ibu mengeluhkan perilaku anak saat sering membanting atau merusak benda saat sedang marah, $20 \%$ ibu mengeluhkan perilaku anak saat tidak mau mendengarkan perkataan orangtuanya, dan $18 \%$ ibu mengeluhkan perilaku anak saat merebut mainan yang sedang digunakan oleh anak lain. Oleh karena itu, pendisiplinan perlu diterapkan oleh ibu pada anak usia 3-5 tahun agar dapat mengarahkan perilaku anak menjadi perilaku yang diharapkan (desirable behavior). Mengacu pada 
kondisi tersebut, maka dapat dikatakan bahwa pendisiplinan perlu dilakukan sejak usia prasekolah.

Berkaitan dengan strategi pendisiplinan, Santrock (2011) menjabarkan tiga strategi pendisiplinan yang dikembangkan oleh Hoffman, yaitu strategi penarikan kasih sayang (love withdrawal), penegasan kekuatan (power assertion), dan penalaran induksi (inductive reasoning). Penarikan kasih sayang adalah teknik pendisiplinan yang dilakukan orangtua dengan cara menarik perhatian atau kasih sayang kepada anak. Contoh penerapan penarikan kasih sayang adalah mengabaikan anak atau mengatakan ketidaksukaan pada anak. Penegasan kekuatan adalah teknik pendisiplinan yang dilakukan orangtua dengan cara mengontrol anak atau sumber daya anak. Contoh penerapan penegasan kekuatan adalah dengan memberi hukuman, memukul, mengancam, atau mengambil apa yang disukai anak. Sementara itu, penalaran induksi adalah teknik pendisiplinan yang dengan menggunakan nalar dan dengan cara menyampaikan bagaimana perilaku anak dapat berdampak pada orang lain. Contoh penerapan penalaran induksi adalah menjelaskan konsekuensi yang dapat terjadi dari perilaku anak, seperti memukul dapat menyebabkan orang lain kesakitan, mengejak dapat membuat orang lain merasa sedih, dan sebagainya.

Beberapa penelitian telah mencoba untuk menggambarkan bentuk penerapan ketiga strategi pendisiplinan tersebut. Salah satunya adalah penelitian yang dilakukan oleh Applegate, Burke, Burleson, Delia, dan Kline (dalam Vangelisti, 2004). Applegate, et al. (dalam Vangelisti, 2004) mengembangkan skema tingkatan strategi pendisiplinan menjadi 6 tingkatan. Strategi pendisiplinan dilihat dari cara orangtua mengembangkan kemampuan anak dalam melakukan refleksi atas perilakunya. Cara-cara tersebut antara lain dengan mempertimbangkan alasan anak dalam berperilaku, memberikan pilihan perilaku kepada anak, dan menjelaskan konsekuensi dari perilaku anak.

Tingkat terendah (tingkat 1) pada skema ini menggambarkan penerapan penegasan kekuatan, sedangkan tingkat tertinggi (tingkat 6) menggambarkan penerapan strategi penalaran induksi. Pada skema ini, strategi penarikan kasih sayang tidak disebutkan karena penerapannya dianggap sudah termasuk dalam kategori penegasan kekuatan. Adapun bentuk perilaku dari 6 tingkatan dalam skema ini antara lain: 1) tingkat 1 ditunjukkan dalam bentuk perintah sederhana, ancaman, atau hukuman; 2) tingkat 2 ditunjukkan dalam bentuk menyatakan peraturan tanpa penjelasan dan tanpa menanyakan pendapat anak tentang peraturan tersebut; 3) tingkat 3 ditunjukkan dalam bentuk menjelaskan konsekuensi fisik dari perilaku anak yang dianggap menyimpang; 4) tingkat 4 ditunjukkan dalam bentuk memberikan pilihan perilaku dan konsekuensi yang harus dijalani atau membuat kesepakatan dengan anak; 5) tingkat 5 ditunjukkan dalam bentuk menjelaskan konsekuensi psikologis dan saran alternatif perilaku kepada anak; 6) tingkat 6 ditunjukkan dalam bentuk menanyakan konsekuensi psikologis dan alternatif perilaku kepada anak.

Kelebihan dari skema ini adalah adanya perhatian pada keunikan dari perasaan setiap anak yang ditunjukkan dalam upaya refleksi atas perilaku masing-masing anak. Selain itu, skema ini tidak hanya melihat dua titik ekstrim dari penegasan kekuatan dan penalaran induksi, tetapi juga menjelaskan tingkat menengah, yaitu saat orangtua menjelaskan konsekuensi fisik atau membuat penawaran dengan anak (tingkat 3 dan 4). Tingkat 3 dan 4 ini menunjukkan adanya tingkatan pendisiplinan yang dapat diupayakan lebih mudah oleh orangtua untuk mencapai pendisiplinan dengan cara penalaran induksi.

Salah satu penelitian yang menggunakan skema tingkatan pendisiplinan oleh Applegate, et al. (1985, dalam Vangelisti, 2004) sebagai alat ukur adalah penelitian yang dilakukan oleh Hart, DeWolf, Wozniak, dan Burts (1992). Hart, et al. (1992) mengukur pendisiplinan yang diterapkan oleh orangtua dengan cara wawancara tentang cara-cara yang digunakan dalam mendisiplinkan anak di beberapa kondisi. Hasil wawancara tersebut diberi skor berdasarkan skema tingkatan pendisiplinan yang dikembangkan oleh Applegate, et al. (dalam Vangelisti, 2004). Alat ukur ini telah terbukti dapat digunakan untuk melihat hubungan antara pendisiplinan anak dengan perkembangan kognitif, perilaku, dan status pertemanan pada anak. Mengacu pada efektivitas teori yang dikembangkan oleh Applegate, et al. (dalam Vangelisti, 2004) dalam mengukur praktik pendisiplinan anak, selanjutnya penelitian ini akan menggunakan kategori strategi pendisiplinan berdasarkan dua strategi, yaitu penegasan kekuatan dan induksi.

Beberapa penelitian telah membahas tentang dampak pendisiplinan anak usia prasekolah dengan strategi penegasan kekuatan dan penalaran induksi. Penelitian yang dilakukan oleh Baumrind, Larzlere, dan Owens (2010) menjelaskan tentang pengaruh praktik pengasuhan orangtua dengan strategi penegasan kekuatan terhadap perkembangan anak hingga dewasa yang dilihat dari kesehatan dan kompetensi emosionalnya. Dalam penelitian tersebut, orangtua yang memiliki kecenderungan menerapkan strategi penegasan kekuatan diklasifikasikan dalam kelompok orangtua yang otoritatif, permisif, dan tidak terlibat. Hasil penelitian tersebut menunjukkan bahwa orangtua yang menerapkan strategi penegasan kekuatan sejak anak masih berusia prasekolah memberikan dampak negatif kepada perkembangan anaknya saat sudah dewasa. Sejalan dengan hasil temuan tersebut, penelitian yang dilakukan oleh Olson, Tardif, Miller, Felt, Grabell, Kessler, Wang, Karasawa, dan Hiraba- 
yashi (2011) kepada 120 orangtua di Amerika, Cina, dan Jepang yang memiliki anak berusia 4 tahun membuktikan bahwa penerapan praktik pendisiplinan dengan kekerasan merupakan salah satu prediktor masalah perilaku eksternal pada anak. Kedua penelitian tesebut menunjukkan bahwa pendisiplinan anak dengan strategi penegasan kekuatan dapat memberikan dampak jangka panjang yang negatif pada perkembangan anak, khususnya dari aspek sosioemosionalnya.

Sementara itu, penelitian lain dilakukan untuk melihat dampak yang ditimbulkan dari praktik pengasuhan dengan strategi penalaran induksi. Ramaswamy dan Bergin (2009) meneliti tentang efek penggunaan strategi reinforcement dan penalaran induksi pada anak prasekolah. Hasil penelitian tersebut menunjukkan bahwa strategi penalaran induksi memberikan dampak positif pada perkembangan afeksi anak yang ditunjukkan dengan peningkatan pemahaman anak bahwa tindakan agresif bukan cara menyelesaikan masalah. Selain itu, anak yang mendapatkan perlakuan dengan perpaduan antara strategi reinforcement dan penalaran induksi lebih memahami tentang perasaan orang lain jika diperlakukan dengan tindakan agresif. Penelitian lain yang membahas tentang praktik pendisiplinan masih berkembang. Salah satu penelitian terbaru yang dilakukan oleh Saltali dan Imir (2018) melihat pengaruh pola asuh yang direpresentasikan dengan strategi penalaran induksi, kehangatan, dan hukuman terhadap kemunculan perilaku sosial anak. Hasil temuan dari penelitian tersebut menunjukkan bahwa pola asuh yang tidak menerapkan strategi penalaran induksi menyebabkan munculnya masalah perilaku sosial, seperti agresif atau pemalu/menarik diri, sedangkan anak yang mendapatkan pola asuh secara penalaran induksi menunjukkan perilaku prososial lebih baik. Dari kedua penelitian tersebut, dapat dikatakan bahwa strategi penalaran induksi dapat memberikan dampak positif pada perilaku anak. Mengacu pada penelitian terkait dampak pendisiplinan anak usia prasekolah dengan strategi penegasan kekuatan dan penalaran induksi, tampak bahwa penalaran induksi merupakan strategi yang lebih efektif untuk mendisiplinkan anak. Oleh karena itu, ibu perlu mengetahui tentang metode pendisiplinan dengan strategi penalaran induksi untuk anak prasekolah.

Sehubungan dengan peningkatan pengetahuan ibu, sebelumnya upaya yang dilakukan ibu dalam menambah pengetahuan tentang pengasuhan lebih banyak dilakukan dengan cara membaca buku, konsultasi tatap muka dengan tenaga ahli (misalnya psikolog), atau menghadiri seminar dan pelatihan untuk orangtua. Sejak hampir tiga dekade terakhir (sekitar tahun 1990), kemajuan teknologi memberi dampak pada kecenderungan ibu dalam mencari sumber informasi menggunakan gawai dan internet. Adanya perkembangan sumber informasi melalui gawai dan internet ini di- jelaskan oleh Lupton, Pedersen, dan Thomas (2016) dalam tinjauan ulangnya tentang pengasuhan dan media digital. Tinjauan ulang tersebut menunjukkan bahwa perkembangan sumber informasi pengasuhan menggunakan gawai dan internet diawali dari berkembanganya situs internet (website) dan forum diskusi online melalui blog. Kemudian, sumber informasi online ini terus berkembang pada penggunaan media sosial, seperti Facebook, YouTube, Pinterest, Twitter, dan Instagram. Selain itu, saat ini telah berkembang juga aplikasi yang dirancang khusus sebagai sumber informasi tentang pengasuhan, misalnya aplikasi untuk ibu hamil atau aplikasi pemantauan perkembangan anak. Aplikasi pertukaran pesan juga telah berperan sebagai sumber informasi pengasuhan bagi ibu. Penggunaan gawai dan internet sebagai sumber informasi semakin meningkat karena dapat memudahkan penggunanya untuk mengakses informasi di manapun. Selain untuk mencari informasi, fitur dan aplikasi yang ada pada gawai dan internet juga dapat digunakan untuk mendapatkan dukungan dan berbagi pengalaman bersama orang lainnya melalui berbagai cara. Tingginya frekuensi penggunaan gawai dan internet oleh ibu dapat dimanfaatkan untuk melakukan intervensi pengasuhan kepada ibu.

Salah satu contoh penggunaan sistem online untuk pembelajaran atau intervensi tentang pengasuhan adalah Triple P-Positive Parenting Program versi online yang telah dilakukan oleh Dittman, Farruggia, Palmer, Sanders, dan Keown (2014). Intervensi dalam penelitian ini dilakukan menggunakan situs internet (website). Adapun media yang digunakan dalam penyampaian materi intervensi dalam penelitian tersebut adalah dalam bentuk infografis, video dan rekaman suara.

Selain menggunakan situs internet, beberapa aplikasi atau program yang dapat digunakan untuk mengadakan seminar online saat ini adalah Skype, Webinar, Instagram (dengan fitur Live), Whatsapp Messenger, dan Telegram. Dari beragam pilihan aplikasi tersebut, studi pendahuluan yang dilakukan oleh peneliti menunjukkan bahwa Whatsapp Messenger menjadi aplikasi yang paling sering digunakan oleh orangtua (terutama ibu) saat ini untuk mengikuti seminar online yang membahas tentang pengasuhan anak. Dari 15 responden yang pernah mengikuti seminar online, sebanyak 14 responden menyatakan paling sering menggunakan aplikasi Whatsapp Messenger aplikasi untuk mengikuti seminar online. Temuan ini menjadi dasar pilihan peneliti dalam menentukan aplikasi yang digunakan untuk intervensi dalam penelitian ini.

Berkaitan dengan meningkatnya penggunaan teknologi online untuk tujuan pembelajaran, terdapat salah satu penelitian yang membuktikan bahwa pembelajaran yang dilakukan secara online juga dapat memberikan hasil yang sama dengan pembelajaran yang dilakukan secara tatap muka. Penelitian yang dilakukan oleh Nguyen (2015) yang 
menunjukkan bahwa peserta yang mengikuti proses pembelajaran secara online memberikan hasil positif yang signifikan. Hasil positif dari pembelajaran secara online dapat dilihat dari beberapa aspek, antara lain nilai ujian, perhatian peserta terhadap materi kelas, persepsi peserta tentang belajar dengan sistem online, interaksi yang terjadi antar peserta, dan jumlah peserta yang bertahan selama kelas berlangsung. Selain itu, sistem pembelajaran online juga dinilai dapat mendukung sistem pembelajaran tatap muka. Misalnya, seseorang dapat memahami materi terlebih dahulu secara online dengan waktu yang lebih efektif, sehingga dapat menghasilkan bahan diskusi yang lebih matang saat digunakan dalam kelas yang dilaksanakan secara tatap muka langsung.

Mengacu pada teori dan data yang telah dipaparkan di atas, dapat disimpulkan bahwa ibu memiliki peran yang penting dalam pengasuhan, khususnya dalam pendisiplinan anak. Pendisiplinan anak perlu diterapkan sejak usia prasekolah. Akan tetapi, pengetahuan ibu tentang pendisiplinan anak di usia prasekolah masih perlu ditingkatkan lagi karena persentase penerapan pendisiplinan dengan cara menghukum masih cukup besar. Oleh karena itu, penelitian ini dilakukan dengan tujuan memberikan intervensi kepada ibu terkait dengan pendisiplinan anak, khususnya tentang strategi induksi.

Intervensi akan dilakukan dalam bentuk seminar online menggunakan aplikasi Whatsapp Messenger, sebagai salah satu aplikasi online yang paling banyak digunakan oleh ibu. Media yang digunakan untuk penyampaian materi dalam intervensi ini berupa infografis dan rekaman suara yang dikirimkan melalui pesan dalam fitur grup pada aplikasi Whatsapp Messenger. Jika ditinjau dengan taksonomi Bloom, intervensi ini dilakukan untuk meningkatkan kemampuan kognitif ibu hingga tahap pemahaman (comprehension). Kemampuan kognitif yang akan diukur meliputi pemahaman tentang karakteristik perkembangan anak prasekolah (perkembangan fisik-motorik, kognitif, bahasa, dan sosioemosional); perilaku negatif yang sering muncul pada anak prasekolah (momen-momen munculnya perilaku negatif, alasan anak melakukan perilaku negatif); serta konsep strategi pendisiplinan anak (strategi yang perlu dihindari, strategi yang dapat dilakukan, dampak penerapan strategi pendisiplinan terhadap perkembangan anak). Hipotesis dalam penelitian ini adalah seminar online merupakan cara yang efektif untuk meningkatan pengetahuan ibu tentang pendisiplinan anak.

\section{METODE}

Teknik pengambilan sampel dalam penelitian ini dilakukan dengan metode purposive sampling. Metode puposive sampling dipilih agar subjek yang diperoleh se- suai dengan karakteristik yang diperlukan dalam penelitian ini. Adapun karakteristik subjek dalam penelitian ini antara lain:1) ibu yang memiliki anak berusia 3 hingga 5 tahun, tidak termasuk anak berkebutuhan khusus; 2) berusia 25-35 tahun; 3) pendidikan minimal S1; 4) latar belakang pekerjaan dan/atau pendidikan bukan di bidang psikologi dan/atau pendidikan anak usia dini; 5) memiliki akses dan mampu menggunakan aplikasi Whatsapp Messenger. Jumlah subjek yang bersedia mengikuti penelitian di awal sebanyak 33 orang. Setelah disesuaikan dengan kiteria yang telah ditentukan, didapatkan subjek sebanyak 18 orang. Kemudian, subjek yang mengikuti seluruh rangkaian penelitian ini sebanyak 14 orang karena 4 orang subjek tidak mengikuti seminar online sesi kedua.

Perekrutan subjek dalam penelitian ini dilakukan dengan memanfaatkan e-flyer yang akan disebarkan melalui media sosial. Media sosial yang digunakan adalah Instagram (melalui fitur Instagram Story) dan Whatsapp (melalui fitur Whatsapp Broadcast dan Whatsapp Story). Karakteristik subjek yang dibutuhkan dan tautan formulir pendaftaran secara online dicantumkan di dalam e-fly$e r$, sehingga calon subjek yang sesuai dengan kriteria dan bersedia untuk mengikuti penelitian dapat langsung mendaftar.

Penelitian ini dilaksanakan selama 2 minggu. Pada minggu pertama, peneliti melaksanakan pertemuan secara tatap muka dengan subjek untuk penjelasan teknis seminar, pengisian informed consent, dan pengerjaan pre-test. Seluruh subjek yang telah mengisi informed consent dimasukkan ke dalam grup Whatsapp. Setelah itu, pada minggu kedua, seminar dilaksanakan secara online sebanyak dua kali dengan durasi masing-masing sesi adalah sekitar 2-2,5 jam. Setelah seminar online kedua selesai, subjek diminta untuk mengerjakan post-test melalui formulir online. Berikut ini gambaran pelaksanaan seminar online.

Pendataan peserta dilakukan dengan cara meminta subjek mengirimkan pesan simbol (contoh: bagi yang sudah online dan menyimak percakapan dalam grup Whatsapp, diminta untuk mengirimkan simbol centang). Setelah semua subjek siap mengikuti seminar online, seminar dibuka dan dilanjutkan dengan penyampaian materi. Materi pada hari pertama meliputi aspek perkembangan dan karakteristik perkembangan anak usia 3-5 tahun (Copple \& Bredekamp, 2009; Santrock, 2011; Papalia \& Martorell, 2014; Charlesworth, 2017), perilaku negatif yang masih sering muncul pada anak usia 3-5 tahun (Sanders, 1992), momen munculnya perilaku negatif anak (Sanders, 1992), alasan yang dapat mendasari munculnya perilaku negatif anak (Dreikurs dalam Essa, 2014), definisi disiplin (Essa, 2011; Santrock, 2011), respon pendisiplinan yang perlu dihindari oleh orangtua (Sanders, 1992), dan dampak penerapan pendisiplinan 
yang kurang tepat pada anak (Baumrind, et al., 2010; Olson, et al., 2011). Sementara itu, materi kedua meliputi penjelasan tentang disiplin positif, manfaat menerapkan disiplin positif (Ramaswamy \& Bergin, 2009; Saltali \& Imir, 2018), strategi pendisiplinan anak (Applegate, et al., dalam Vangelisti, 2004), konsep konsekuensi (Applegate, et al., dalam Vangelisti, 2004; Henniger, 2009), dan tingkatan praktik pendisiplinan anak (Applegate, et al., dalam Vangelisti, 2004). Materi disampaikan dalam waktu 45-60 menit dalam bentuk infografis dan rekaman suara. Berikut ini contoh infografis yang digunakan dalam materi intervensi.

Tabel 1. Rincian Pelaksanaan Seminar Online Pendisiplinan Anak

\begin{tabular}{|c|c|c|c|c|}
\hline No & Kegiatan & Metode & Pelaksana & Durasi \\
\hline \multicolumn{5}{|c|}{ Hari ke-1 } \\
\hline 1. & $\begin{array}{l}\text { Pendataan } \\
\text { peserta }\end{array}$ & $\begin{array}{c}\text { Cek } \\
\text { secara } \\
\text { online }\end{array}$ & Kofasilitator & 5 \\
\hline 2. & Pembukaan & Ceramah & Kofasilitator & $5^{\prime}$ \\
\hline 3. & $\begin{array}{c}\text { Materi } \\
\text { pertama }\end{array}$ & Ceramah & Fasilitator & $60^{\prime}$ \\
\hline 4. & Tanya jawab & Diskusi & Fasilitator & $60^{\prime}$ \\
\hline 5. & Penutupan & Ceramah & Kofasilitator & 5 , \\
\hline \multicolumn{5}{|c|}{ Hari ke-2 } \\
\hline 1. & $\begin{array}{l}\text { Pendataan } \\
\text { peserta }\end{array}$ & $\begin{array}{c}\text { Cek } \\
\text { secara } \\
\text { online }\end{array}$ & Kofasilitator & $5^{\prime}$ \\
\hline 2. & Pembukaan & Ceramah & Kofasilitator & 5 \\
\hline 3. & $\begin{array}{l}\text { Materi } \\
\text { kedua }\end{array}$ & Ceramah & Fasilitator & $60^{\prime}$ \\
\hline 4. & Tanya jawab & Diskusi & Fasilitator & $60^{\prime}$ \\
\hline 5. & $\begin{array}{c}\text { Pengisian } \\
\text { post-test } \\
\text { melalui } \\
\text { formulir } \\
\text { online } \\
\end{array}$ & Ceramah & Kofasilitator & $20^{\prime}$ \\
\hline 6 & Penutupan & Ceramah & Kofasilitator & 5 \\
\hline
\end{tabular}

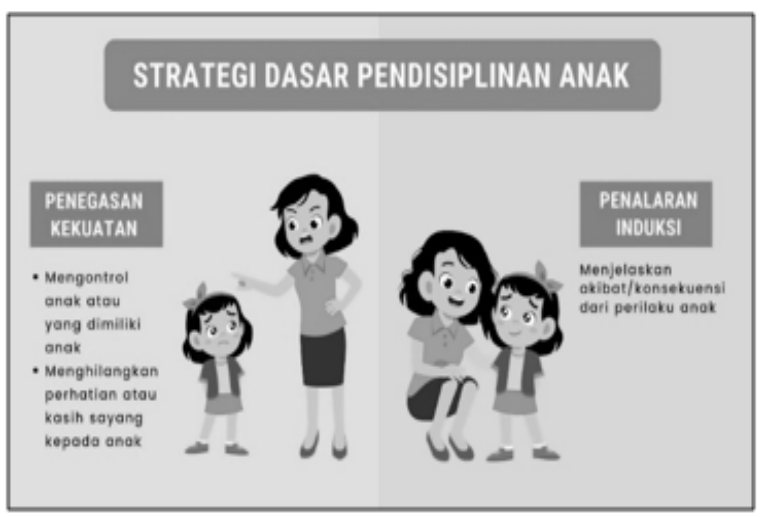

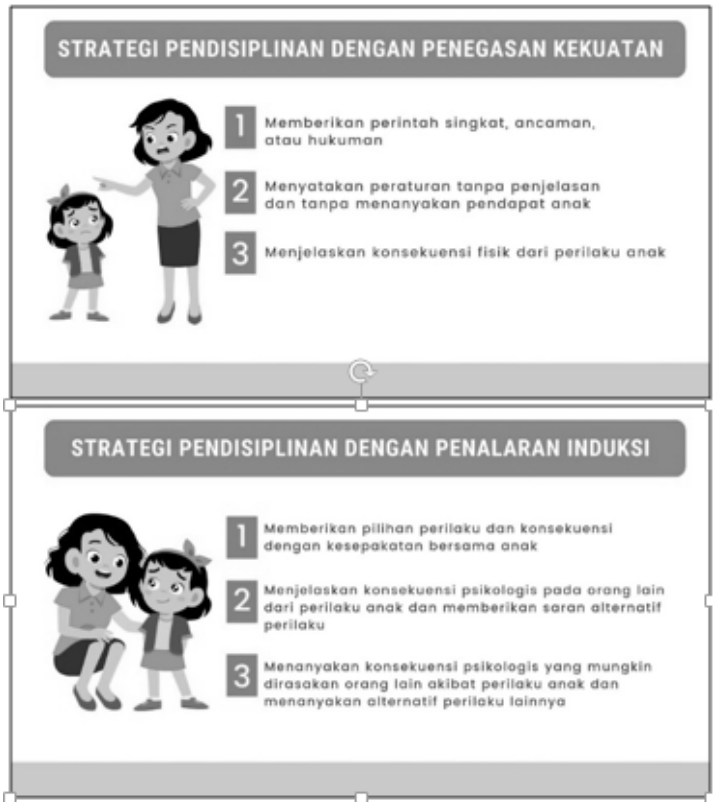

Gambar 1. Contoh infografis materi intervensi

Setelah penyampaian materi selesai, subjek dapat berdiskusi atau bertanya tentang topik yang telah dibahas selama 60 menit. Teknis pelaksanaan seminar pada hari kedua masih sama. Pada seminar hari kedua, subjek diminta untuk mengerjakan post-test menggunakan formulir online terlebih dahulu sebelum seminar ditutup.

Penelitian ini menggunakan alat ukur pertanyaan sesuai dengan konten materi yang telah disusun dan dinilai oleh ahli di bidang psikologi perkembangan dan pendidikan anak usia dini. Alat ukur ini terdiri dari 17 item. Sebanyak 15 item dalam alat ukur ini adalah pertanyaan terbuka dan 2 item dalam alat ukur ini adalah pilihan ganda (ya atau tidak). Adapun rincian itemnya antara lain 5 item tentang perkembangan anak usia 3-5 tahun, 3 item tentang perilaku negatif anak usia 3-5 tahun, dan 9 item tentang strategi pendisiplinan anak. Berikut ini merupakan contoh item dalam alat ukur penelitian ini.

Tabel 2. Contoh item dalam alat ukur penelitian

\begin{tabular}{|l|l|}
\hline \multicolumn{1}{|c|}{ Aspek } & \multicolumn{1}{c|}{ Item } \\
\hline $\begin{array}{l}\text { Perkembangan anak } \\
\text { usia 3-5 tahun }\end{array}$ & $\begin{array}{l}\text { Apa ciri khas perkembangan } \\
\text { fisik-motorik anak usia 3-5 tahun? } \\
\text { Apa ciri khas perkembangan kog- } \\
\text { nitif anak usia 3-5 tahun? } \\
\text { Apa ciri khas perkembangan baha- } \\
\text { sa anak usia 3-5 tahun? } \\
\text { Apa perilaku negatif yang masih } \\
\text { sering muncul pada anak usia 3-5 } \\
\text { tahun? } \\
\text { usia 3-5 tahun } \\
\text { Apa alasan dasar anak melakukan } \\
\text { perilaku negatif? } \\
\text { Apa yang dimaksud dengan pe- } \\
\text { nalaran induksi? } \\
\text { siplinan anak }\end{array}$ \\
$\begin{array}{l}\text { Apakah penalaran induksi mer- } \\
\text { upakan strategi yang tepat dalam } \\
\text { pendisiplinan? }\end{array}$ \\
\hline
\end{tabular}


Pengisian alat ukur dilakukan oleh subjek secara online melalui Google form. Peneliti memberikan tautan yang terhubung pada Google form kepada subjek melalui grup Whatsapp. Analisis data menggunakan uji statistik non parametrik Wilcoxon dengan membandingkan gain score.

\section{HASIL DAN PEMBAHASAN}

Data kuantitatif dalam penelitian ini adalah data dari 14 subjek yang telah mengikuti pre-test, seminar online selama 2 sesi, dan post-test. Perbandingan nilai pre-test dan post-test dianalisis untuk melihat ada atau tidaknya perbedaan yang signifikan setelah subjek mendapatkan intervensi berupa seminar online. Peneliti melakukan uji non parametric Wilcoxon Signed Rank untuk mengetahui apakah ada perbedaan signifikan antara nilai pre-test dan post-test. Hasil uji tersebut dapat dilihat pada tabel berikut ini.

Tabel 3. Hasil Uji Perbedaan Skor Pengetahuan Subjek Sebelum dan Sesudah Intervensi

\begin{tabular}{|l|r|}
\hline \multicolumn{2}{|c|}{ Posttest - Pretest } \\
\hline$Z$ & $-3,299^{\mathrm{b}}$ \\
\hline Asymp. Sig. (2-tailed) &, 001 \\
\hline
\end{tabular}

Berdasarkan tabel di atas, nilai $Z$ yang didapat sebesar $-3,299$ dengan $p$ value (Asymp.Sig 2 tailed) sebesar 0,001. Nilai $p$ value kurang dari 0,05 menunjukkan bahwa ada perbedaan yang signifikan antara nilai pre-test (sebelum dilakukan intervensi seminar online) dan post-test (setelah dilakukan intervensi seminar online), sehingga dapat dikatakan bahwa seminar online mampu meningkatkan pengetahuan ibu tentang strategi penalaran induksi dalam pendisiplinan anak prasekolah. Berikut ini gambaran skor pre-test, posttest, dan gain score yang diperoleh masing-masing subjek berdasarkan kuesioner.

Tabel 4. Data Deskriptif Skor Pengetahuan Subjek tentang Pendisiplinan Anak berdasarkan Kuesioner

\begin{tabular}{|c|c|c|c|}
\hline Subjek & Pre-test & Post-test 1 & Gain Score \\
\hline S1 & 17 & 21 & 4 \\
\hline S2 & 19 & 35 & 16 \\
\hline S3 & 25 & 36 & 11 \\
\hline S4 & 21 & 32 & 11 \\
\hline S5 & 16 & 42 & 26 \\
\hline S6 & 15 & 38 & 23 \\
\hline S7 & 5 & 26 & 21 \\
\hline S8 & 13 & 38 & 25 \\
\hline S9 & 13 & 44 & 31 \\
\hline S10 & 16 & 42 & 26 \\
\hline
\end{tabular}

\begin{tabular}{|c|c|c|c|}
\hline S11 & 13 & 28 & 15 \\
\hline S12 & 10 & 14 & 4 \\
\hline S13 & 14 & 33 & 19 \\
\hline S14 & 8 & 24 & 16 \\
\hline
\end{tabular}

Tabel 5. Data Deskriptif Gain Score Pengetahuan tentang Pendisiplinan Anak

\begin{tabular}{|c|c|c|c|c|c|}
\hline \multicolumn{2}{|l|}{ N } & Min. & Max. & Mean & $\begin{array}{l}\text { Std. } \\
\text { Devia- } \\
\text { tion }\end{array}$ \\
\hline Gainscore & 14 & 4 & 31 & 17,71 & 8,260 \\
\hline
\end{tabular}

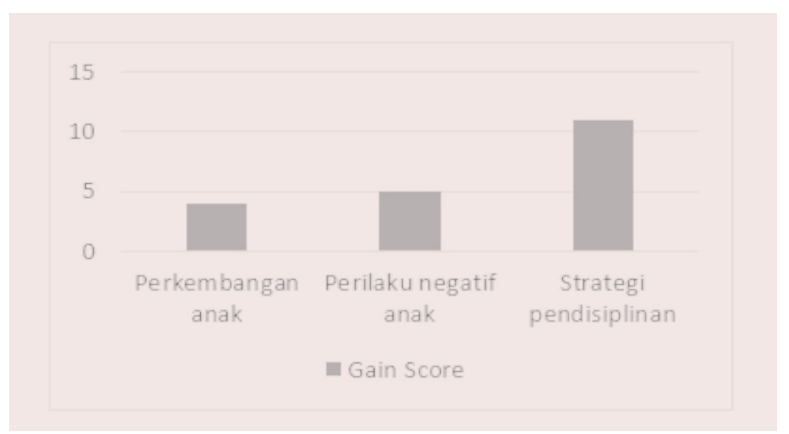

Grafik 1. Rata-rata Gain Score pada Aspek Pengetahuan Subjek

Berdasarkan data yang tercantum pada tabel 4 dan tabel 5, dapat dilihat gain score atau perubahan nilai terendah adalah sebesar 4 poin yang diperoleh subjek 1 dan 12 , sedangkan perubahan nilai tertinggi adalah sebesar 31 poin yang diperoleh subjek 9. Rata-rata perubahan nilai yang diperoleh adalah sebesar 17,71 poin. Mengacu pada grafik 1, dapat dilihat bahwa rata-rata gain score tertinggi tampak pada aspek pengetahuan yang berhubungan dengan strategi pendisiplinan.

Secara rinci, berkaitan dengan penalaran induksi, saat pre-test seluruh subjek menjawab tidak mengetahui strategi penalaran induksi, apakah strategi penalaran induksi efektif untuk mendisiplinkan anak, dan apa dampak strategi penalaran induksi terhadap perkembangan anak. Kemudian, saat post-test seluruh subjek dapat menjawab definisi disiplin penalaran induksi, manfaat penalaran induksi dalam pendisiplinan, dan seluruh subjek mengetahui bahwa penalaran induksi adalah strategi yang efektif dalam pendisiplinan anak. Peningkatan skor seluruh subjek tentang pendisiplinan melalui penalaran induksi ini menunjukkan bahwa penyampaian informasi melalui seminar online dapat meningkatkan pengetahuan ibu tentang strategi penalaran induksi dalam pendisiplinan anak.

Selain data kuantitatif, peneliti juga mendapatkan data kualitatif berupa pengamatan selama seminar online berlangsung dan hasil wawancara dengan subjek setelah seminar online selesai dilaksanakan. Pada saat sesi diskusi dalam seminar online berlangsung, dari total 14 subjek, sebanyak 8 subjek mengajukan pertanyaan. Pertanyaan yang diajukan juga masih berhubungan dengan materi 
yang telah disampaikan, antara lain tentang penerapan strategi penalaran induksi pada kondisi-kondisi tertentu seperti saat anak tidak mau mandi, saat anak berebut mainan dengan temannya, dan sebagainya. Selain itu, pertanyaan lain yang disampaikan juga terkait apakah cara yang telah diterapkan saat ini termasuk penegasan kekuatan, apakah masih boleh menerapkan strategi yang sudah biasa diterapkan sebelumnya, dan bagaimana cara menahan diri agar tidak terbiasa menggunakan strategi penegasan kekuatan. Pertanyaan-pertanyaan yang muncul tersebut masih sangat berhubungan dengan materi yang telah disampaikan. Hal ini menunjukkan bahwa dengan media infografis dan rekaman suara yang berisi penjelasan infografis tersebut cukup dipahami oleh subjek.

Pada saat sesi diskusi, beberapa subjek juga sempat saling berbagi pengalaman tentang kondisi yang terjadi pada anaknya dan strategi yang selama ini dilakukan. Salah satu kondisi yang dirasakan dan ditanyakan oleh sebagian besar subjek adalah kondisi saat anak berebut mainan dengan teman sebayanya. Saat salah satu subjek menanyakan tentang kondisi ini, beberapa subjek lainnya menyebutkan bahwa anaknya juga mengalami hal yang sama dan subjek tersebut ingin menanyakan hal yang serupa. Hal ini menunjukkan bahwa materi yang disampaikan sesuai dengan kebutuhan ibu dalam mendisiplinkan anak.

Kemudian, setelah seminar online selesai diadakan, peneliti sempat melakukan wawancara tatap muka kepada 5 subjek yang dipilih secara acak. Peneliti menanyakan kesan setelah mengikuti seminar online dan hal apa yang paling diingat dari seminar online yang telah diikuti. Dari 5 subjek yang diwawancara, hanya 1 orang yang sudah pernah mengikuti seminar online dengan aplikasi Whatsapp Messenger sebelumnya. Akan tetapi, walaupun hanya 1 orang yang sudah memiliki pengalaman sebelumnya, subjek lainnya menyatakan tidak mengalami kebingungan atau kesulitan dalam menyimak materi dan mengikuti pelaksanaan seminar online dalam penelitian ini. Kelima subjek menyatakan mendapat manfaat dari seminar online ini. Ada yang menyatakan bahwa seminar dengan cara online seperti ini sangat membantu ibuibu, baik yang bekerja maupun ibu rumah tangga untuk tetap dapat menambah pengetahuan tentang anak. Salah satu subjek juga menyatakan bahwa sebelumnya pernah mengikuti seminar tatap muka, tetapi semakin lama semakin jarang karena kesulitan untuk mengatur waktu dan perlu menempuh jarak tertentu untuk bisa mengikuti seminar. Namun, dengan adanya seminar dalam bentuk online, kesempatan dan akses untuk mengikuti seminar semakin mudah. Selain itu, subjek lain juga menjelaskan bahwa dengan penggunaan materi dalam bentuk soft file (infografis dan rekaman suara) yang dapat disimpan da- lam telepon genggam, membuat subjek dapat mengulang kembali materi yang telah disampaikan sehingga dapat membantu dalam proses mengingat dan memahami.

Berkaitan dengan materi yang disampaikan, kelima subjek yang diwawancara mengatakan mendapatkan berbagai pengetahuan baru setelah mengikuti seminar online ini. Adapun poin yang diingat oleh kelima subjek tersebut, antara lain:

1. Seorang ibu perlu memiliki kemampuan untuk mengatur emosinya terlebih dahulu sebelum mengatasi masalah perilaku anak.

2. Cara pendisiplinan yang dilakukan saat anak masih berusia 5 tahun ke bawah memberikan dampak jangka panjang pada perkembangan anak.

3. Strategi penalaran induksi dapat menjadi alternatif cara yang efektif untuk mendisiplinkan anak.

4. Ibu perlu memahami perkembangan anak agar dapat memahami kebutuhan anak.

5. Ibu perlu memahami alasan anak melakukan perilaku negatif agar respon yang diberikan kepada anak tepat.

Selain itu, peneliti juga melakukan wawancara kepada subjek yang memperoleh gain score terendah dan tertinggi. Berdasarkan hasil wawancara tersebut, peneliti mendapat kesimpulan bahwa kecenderungan gaya belajar subjek berpengaruh pada informasi yang diingat. Subjek dengan gain score tertinggi memiliki kecenderungan gaya belajar visual auditori, sesuai dengan media yang digunakan oleh peneliti dalam seminar online. Selain itu, subjek yang memperoleh gain score tertinggi juga merasa bahwa materi intervensi sesuai dengan informasi yang sedang dicari dan dibutuhkan. Setelah mengikuti seminar online ini, subjek merasa perlu banyak memperbaiki pola pendisiplinan pada anaknya dan sedang berusaha menerapkan cara pendisiplinan dengan cara penalaran induksi.

Sementara itu, subjek dengan gain score terendah memiliki kecenderungan auditori dan cenderung lebih mudah menjelaskan apa yang dipahami secara lisan dibandingkan tulisan. Mengacu pada kondisi tersebut, pada saat wawancara, peneliti mencoba menggali kembali pengetahuan subjek tersebut tentang materi yang sudah disampaikan pada saat seminar online. Dari hasil wawancara, subjek dengan gain score terendah sebenarnya memahami materi yang disampaikan. Gain score yang diperoleh rendah karena performa subjek tersebut kurang maksimal melalui tulisan.

\section{SIMPULAN}

Hasil penelitian ini membuktikan bahwa intervensi pada ibu dalam bentuk seminar online dapat meningkatkan pengetahuan ibu tentang strategi penalaran 
induksi dalam pendisiplinan anak. Penggunaan intervensi dalam bentuk seminar online dirasa memberi kemudahan dan fleksibilitas bagi ibu untuk dapat belajar dan mengulang kembali materi yang telah disampaikan pada saat seminar. Hal ini sesuai dengan penelitian terdahulu yang dilakukan oleh Nguyen (2015). Penggunaan aplikasi Whatsapp Messenger yang merupakan aplikasi yang banyak digunakan oleh para ibu saat ini juga mendukung kemudahan ibu untuk mengakses dan mengoperasikan media yang digunakan saat seminar online. Adanya sesi diskusi juga membantu ibu lebih banyak membahas tentang praktik pendisiplinan sehari-hari pada anak. Bentuk materi yang diberikan dalam bentuk infografis dan rekaman suara juga menjadi hal yang dapat mendukung peningkatan pengetahuan ibu karena dapat memfasilitasi kebutuhan gaya belajar visual maupun auditori. Hal ini menjadi faktor pendukung yang dapat meningkatkan efektivitas dalam pelaksanaan seminar online. Oleh karena itu, dapat dikatakan bahwa kekuatan dari penelitian ini adalah metode intervensi yang digunakan lebih fleksibel untuk ibu bekerja maupun ibu rumah tangga, aplikasi yang dipilih sudah sering digunakan oleh ibu, topik yang dipilih sesuai dengan fenomena yang banyak terjadi pada ibu yang memiliki anak usia 3-5 tahun, dan bentuk materi yang disampaikan menunjang kecenderungan gaya belajar baik yang visual maupun auditori walaupun tidak bertatap muka langsung. Berdasarkan hal tersebut, dapat disimpulkan bahwa seminar online dengan aplikasi Whatsapp Messenger efektif untuk meningkatkan pengetahuan ibu tentang strategi penalaran induksi dalam pendisiplinan anak prasekolah.

Saran yang dapat diberikan kepada peneliti selanjutnya adalah memperbanyak frekuensi seminar dan menambah sesi diskusi dengan subjek. Selain itu, seminar juga dapat dilakukan secara gabungan, antara seminar tatap muka dengan seminar online. Seminar online dapat dilakukan untuk pemberian materi dasar yang lebih bersifat teoritis, sedangkan seminar tatap muka dapat dilakukan untuk pelatihan praktik pendisiplinan dengan strategi penalaran induksi kepada anak. Hal ini dapat dilakukan untuk memfasilitasi kebutuhan gaya belajar dengan kecenderungan kinestetik dan juga menambah kemampuan ibu, tidak hanya sebatas kognitif tetapi juga psikomotor. Penelitian dengan topik serupa juga dapat dilakukan bersama antara ibu dan ayah.

\section{DAFTAR PUSTAKA}

Ball, C. L., Smetana, J. G., Sturge-Apple, M. L., Suor, J. H., \& Skibo, M. A. (2017). Moral development in context: Associations of neighborhood and maternal discipline with preschoolers' moral judgments.
Developmental Psychology, 53(10), 1881-1894. https://doi.org/10.1037/dev0000378

Baumrind, D., Larzelere, R. E., \& Owens, E. B. (2010). Effects of preschool parents' power assertive patterns and practices on adolescent development. Parenting, 10(3), 157-201. https://doi. org/10.1080/15295190903290790

Davidov, M., Grusec, J. E., \& Wolfe, J. L. (2012). Mothers' knowledge of their children's evaluations of discipline: The role of type of discipline and misdeed, and parenting practices. Merrill-Palmer Quarterly (1982-), 314-340.

Dittman, C. K., Farruggia, S. P., Palmer, M. L., Sanders, M. R., \& Keown, L. J. (2014). Predicting success in an online parenting intervention: The role of child, parent, and family factors. Journal of Family Psychology, 28(2), 236-243. https://doi. org/10.1037/a0035991

Hart, C. H., DeWolf, D. M., Wozniak, P., \& Burts, D. C. (1992). Maternal and Paternal Disciplinary Styles: Relations with Preschoolers' Playground Behavioral Orientations and Peer Status. Child Development, 63(4), 879-892. https://doi. org/10.1111/j.1467-8624.1992.tb01668.x

Hallers-Haalboom, E. T., Groeneveld, M. G., van Berkel, S. R., Endendijk, J. J., van der Pol, L. D., Bakermans-Kranenburg, M. J., \& Mesman, J. (2015). Wait until your mother gets home! mothers' and fathers' discipline strategies. Social Development, 25(1), 82-98.

Henniger, M. L. (2009). Teaching young children (4th ed.). New Jersey: Pearson.

Lucassen, N., Kok, R., Bakermans-Kranenburg, M. J., Van Ijzendoorn, M. H., Jaddoe, V. W. V., Hofman, A., ... Tiemeier, H. (2015). Executive functions in early childhood: The role of maternal and paternal parenting practices. British Journal of Developmental Psychology, 33(4), 489-505. https://doi. org/10.1111/bjdp.12112

Lupton, D., Pedersen, S., \& Thomas, G. M. (2016). Parenting and Digital Media: From the Early Web to Contemporary Digital Society. Sociology Compass, 10(8), 730-743. https://doi.org/10.1111/ soc4.12398

Nguyen, T. (2015). The Effectiveness of Online Learning: Beyond No Significant Difference and Future Horizons. MERLOT Journal of Online Learning and Teaching, 11(2), 309-319.

Olson, S. L., Tardif, T. Z., Miller, A., Felt, B., Grabell, A. S., Kessler, D., ... Hirabayashi, H. (2011). Inhibitory control and harsh discipline as predictors of externalizing problems in young children: A 
comparative study of U.S.; Chinese, and Japanese preschoolers. Journal of Abnormal Child Psychology, 39(8), 1163-1175. https://doi.org/10.1007/ s10802-011-9531-5

Ramaswamy, V., \& Bergin, C. (2009). Do reinforcement and induction increase prosocial behavior? results of a teacher-based intervention in preschools. Journal of Research in Childhood Education, 23(4), 527-538. https://doi. org/10.1080/02568540909594679

Saltal1, N. D., Protection, C., \& Program, C. S. (2018). Parenting Styles as a Predictor of the Preschool Children 's Social Behaviours Hatice Merve İmir. 5(2), 18-37.
Sanders, M. R. (1992). Every parent a positive approach to children's behaviour. Australia: McPherson's Printing Group

Santrock, J. W. (2011). Child development (13th ed.). New York: McGraw-Hill Companies, Inc.

Saunders, R., McFarland-Piazza, L., Jacobvitz, D., Hazen-Swann, N., \& Burton, R. (2013). Maternal Knowledge and Behaviors Regarding Discipline: The Effectiveness of a Hands-on Education Program in Positive Guidance. Journal of Child and Family Studies, 22(3), 322-334. https://doi. org/10.1007/s10826-012-9581-5

Vangelisti, Anita. (2004). Vangelisti, A. L. (Ed.). (2004). Handbook of family communication. Mahwah, NJ: Lawrence. 